\title{
Pawel Brzegowy, review of: Stéphanie Bessière, Le tourisme des Antilles françaises. Le défi de la concurrence caribéenne, Éditions L'Harmattan, Paris 2010, p. 370.
}

The object of the following review is a study authored by Stéphanie Bessière Le tourisme des Antilles françaises. Le défi de la concurrence caribéenne. The author is a graduate of the Centre d'Études Diplomatiques et Stratégiques de Paris and l'Institut de Recherches et d'Etudes Supérieures du Tourisme de la Sorbonne. The monographic study was divided into an introduction, three parts consisting of minor chapters, two appendices and a bibliography. The study is concluded with a concise historical outline of the Caribbean region [p. 368]. The appearance of the first European discoverers gave rise to the recorded history of the Caribbean. It is not difficult to observe that even in the modern times, the political and economic bonds with Europe are strong. In the epilogue, the researcher expresses a conviction that in the era of the progressing globalisation and in the context of the pursued economic activity, the French Antilles have found themselves at a crossroads - "Les îles françaises de la Caraïbe sont à un carrefour et les choix qui seront effectués impacteront les prochaines décennies" [p. 15]. The first part [pp. 17-34] was given an introductory character leading into the problem area of the French Antilles: Guadalupe and Martinique. Then, the information on the geographical location of the French West Indies was contained, its historical outline and basic economic ratios. The whole Caribbean France was given consideration in the study and therefore, also, the overseas collectivities of Saint-Martin and Saint-Barthélemy. In the second part [pp. 35-142], the author concentrated on the general presentation of the Caribbean, paying attention to its rich tourist potential. The most important island countries and dependable territories, starting from Antigua and Barbuda [p. 41] to finish with the Turks and Caicos Islands [p. 139], were described concisely, but substantially. In the third part of the study [pp.143-352], the most important facts were provided, regarding the competitive environment of the French departments in the Lesser Antilles, viewed in the context of the tourist services market.

In her study, the researcher underlined that the development of the tourist industry in the French Antilles after the year 2000 belongs among the most important sectors of the departmental economies. In the recent years, airport passenger traffic has been increased and also cruise tourism has gained in importance. The vast majority of the tourists visiting Guadalupe and Martinique are metropolitan French, but more and more often also other Europeans appear, mostly Italians and Belgians. Almost half of the vacationists use the regional hotel base during their stay. The author correctly observed that the future development of the regional tourism is determined by the co-operation in various areas, among others, including: promotion of tourist agencies, modernisation of the hotel sector or support for the sustainable tourism. Not without importance are the external (extra-departmental) factors, related to the promotion of the French West Indies' tourist offer. The above defined activities are also forcefully necessitated by the constantly growing competition from the neighbours of the Caribbean departments' in the tourist industry. It was noted in the monographic study that the regional authorities of Guadalupe and Martinique are aspiring to have the number of tourists doubled by forming new tourist centres and enhancing the attractiveness of the tourist offer - the Marie-Galante island among others. 
Efforts are also being made to enhance the promotion of the regional museums, natural objects and cultural events.

Tourism plays an especially important role in the case of Saint-Martin and Saint-Barthélemy. In contrast to the other Caribbean islands, characterised with the dominating mass tourism, the tourist market in the itemized overseas collectivities is, primarily, focused on the well-off tourists. This is caused by the high costs of living and other specific limitations, i.e. difficult access to the potable water. It is assumed that the difference in the maintenance costs between Saint-Barthélemy and Guadalupe amounts to approximately $25 \%$. The island's high level of safety, its harmonised urban development and good infrastructural organisation, mostly attract tourists from North America, who account for $70 \%$ of all its visitors during the season. The Saint-Martin and Saint-Barthélemy hotel accommodation is largely dominated by luxury facilities, managed by specialised companies. The newly emerging vacation homes, intended for rental purposes, facilitate the development of the local construction sector. There is no doubt, which is also accurately proven by the author, that the French part of the Antilles is localised in a special geographical area, where the concept of competitiveness (especially on the tourist market) is extremely important. In accordance with Article 349 of the Treaty on the Functioning of the European Union, Guadalupe and Martinique were qualified as the most peripheral regions (régions ultrapériphériques, RUP), to be treated as the special areas of the EU member states. As a consequence of their specific social and economic conditions, resulting from their geographical distance and isolation, the application of the EU law is subject to certain derogations in this part of the Overseas France.

On the basis of her observations [pp. 353-367], the researcher comes to the conclusion that the French Antilles should primarily concentrate on the development of sustainable tourism (touristique durable). The factors which fundamentally determine the tourist attractiveness of the given region are its natural and cultural assets. The growing number of tourists may endanger the integral character of selected locations or lead to their degradation. Therefore, a rational approach to tourism is so important, considering its diverse connections with the natural environment, the region's cultural values and the social factor. S. Bessière's study is worth resorting to for, at least, two reasons. It is the first study so extensively presenting the French Antilles' tourist market against the Caribbean background in the context of the competitive advantage. Secondly, it lucidly characterises the structural and economic factors, affecting the tourism in the Caribbean coast of the Overseas France. In view of the issue concerned, the study under review will be helpful, not only to the researchers dealing with the geography of tourism, but also to the specialists in the areas of tourism economics, marketing and history. 